\title{
REPUBLIKA SLOVENIJA V NATU - SLOVENSKA VOJSKA DESET LET POZNEJE
}

\author{
REPUBLIC OF SLOVENIA IN NATO - \\ SLOVENIAN ARMED FORCES TEN YEARS LATER
}

Povzetek Republika Slovenija je že deset let članica Nata in članstvo v zavezništvu je znatno prispevalo k razvoju Slovenske vojske. Postala je mednarodno prepoznavna. $\mathrm{S}$ sodelovanjem v mednarodnih operacijah in na misijah prispeva tudi k mednarodni varnosti. Od svojega nastanka se preoblikuje in prilagaja novim razmeram ter sodobnim varnostnim izzivom, tako da lahko učinkovito uporabi kadrovske in materialne vire, ki so na voljo za zagotavljanje vojaških zmogljivosti. Sodeluje v mednarodnih vojaških vajah in deluje v Natu in organih ter poveljstvih EU. V Natu in Slovenski vojski potekajo transformacijski procesi, ki so med seboj povezani. Nekatere rešitve za zagotavljanje in razvoj vojaških zmogljivosti se zagotavljajo s sodelovanjem v projektih pametne obrambe, konceptu povezanih sil in konceptu vodilne države. Slovenska vojska se v zadnjih letih srečuje znenehnim zmanjševanjem finančnih virov, kar otežuje razvoj vojaških zmogljivosti. Zaradi krčenja obrambnega proračuna bo v prihodnosti treba opraviti razmislek o prihodnjih obsegu in strukturi Slovenske vojske ter zagotoviti stabilno financiranje.

Ključne Nato, Slovenska vojska, razvoj, vojaške zmogljivosti, mednarodne operacije in besede misije, obrambni izdatki, standardizacija, transformacija.

Abstract The Republic of Slovenia has now been a member of NATO for ten years, and the membership has significantly contributed to the development of the Slovenian Armed Forces (SAF) which has gained international recognition. By participating in international operations and missions, the SAF also contributes to international security. Since the time of its formation, it has been transforming and adapting to new realities and contemporary security challenges, effectively utilizing the available human and material resources in order to provide the necessary military capabilities. It participates in international military exercises and operates in NATO and EU bodies and commands. Both in NATO and the Slovenian Armed Forces, 
interconnected transformation processes are currently under way. Some solutions that aim to deliver and develop the necessary military capabilities are being provided through participation in Smart Defence projects, the Connected Forces Initiative and the Framework Nations Concept. In recent years, the SAF has been faced with the continuous reduction of financial resources, which hinders the development of military capabilities. In the future, due to the defence budget reductions, it will be necessary to think about the scope and structure of the SAF and provide stable funding.

Key words NATO, Slovenian Armed Forces, development, military capabilities, international operations and missions, defence expenditure, standardization, transformation.

Introduction The defence system of the Republic of Slovenia (hereinafter Slovenia), whose most important part is the Slovenian Armed Forces (hereinafter SAF), has, in the ten years of membership in NATO, successfully completed its tasks and developed rapidly. In these ten years, the SAF has also become internationally recognized, operating in various international operations and missions, and contributing to stability and security in the near and far international environment. Participation in the international environment is an important indicator and the driver of development in the SAF, both in equipping and military education and training. Full membership in two international organizations, the European Union and NATO, is very important for the SAF, both now and in the future. Slovenia has endeavoured to join NATO for reasons of common values, own national and strategic security interests, and the desire to contribute to the security and stability in the European continent. This orientation is also clear in the Resolution on the National Security Strategy of the Republic of Slovenia from 2001 and the new Resolution from $2010^{1}$.

For Slovenia, NATO membership signifies security in the context of collective defence and participation in the activities for regional stability and peace in the international community. Slovenia, as a recognizable and active member of NATO, contributes to the sharing of responsibilities and burdens in providing collective defence, based on solidarity between states, and is actively involved in all processes and activities of NATO. Slovenia is thus strengthening its position as a secure and stable country, which has a positive impact on economic cooperation with other countries in various fields, with a significant contribution of Slovenia. Wider global and regional security challenges, military and asymmetric threats, such as the proliferation of weapons of mass destruction, terrorist and cyber attacks, rightly strengthen the belief that Slovenia's membership in NATO is indeed necessary.

\footnotetext{
Paragraph 3 of item 4.1 (Foreign Policy) of the Resolution on the National Security Strategy of the Republic of Slovenia from 2001 states: "Priority task of the Slovenian foreign policy is the inclusion of the Republic of Slovenia into the European Union and NATO."

Paragraph 1 of item 5.3.8 (Response to Military Threats) of the Resolution on the National Security Strategy of the Republic of Slovenia from 2010 states: "The response of the Republic of Slovenia to military threats will be based on joined efforts and operations within NATO and the European Union. With a view to preventing military threats, the Republic of Slovenia will continue to actively work for a mutual balance of security and defence interests within NATO, the European Union, the Organisation for Security and Cooperation in Europe, the United Nations and other international regional initiatives and forms of cooperation."
} 
Even NATO is constantly faced with new contemporary challenges, such as new crisis areas, cyber threats, the issue of how to stop reduction in defence spending in some NATO countries and increase the provision of defence resources etc. There is the question of enlarging the Alliance with new members, the consideration and approval of the new readiness action plan etc. The NATO Summit in Wales on 4 and 5 September 2014 was devoted to finding solutions and adopting the highest decisions that will strengthen the Alliance to be able to address modern security challenges of the future.

\section{METHODOLOGICAL APPROACH}

The purpose of this article is to review the SAF's progress in certain areas from the time of its entry into NATO, to draw attention to the problem of providing financial resources and reducing defence spending, and to look into the future. In doing so, we want to determine whether NATO membership has allowed the SAF to contribute its share to the Alliance and thus gain added value itself.

In preparing and writing the article, the following methods were used: description, inductive and deductive methods, comparative and statistical methods, and the method of observation through own participation. There are many available statistical data as well as primary and secondary sources in the defence sector and outside, while this article only makes use of several data sources. Given personal experience, the method of observation through own participation was used in the methodological approach, having a significant impact on the selection of data, content and methods for which it has been estimated that they are key for the review of the SAF's progress from the time of its entry into NATO.

\section{DEVELOPMENT AFTER JOINING NATO}

Since 1991, the SAF has developed intensively, but the transition from the system of own defence to the system of collective defence as well as the transition from a conscript to a professional army has had a significant impact on its development. An important milestone was the period of the first NATO enlargement, when Slovenia was not invited to join NATO. This failure to join NATO was also discussed by the Committee on Defence of the National Assembly of the Republic of Slovenia ${ }^{2}$. Nevertheless, the SAF, together with the Ministry of Defence and other government bodies continued to intensively prepare for entry into the Alliance. Thus, in 2004, when Slovenia did join the Alliance, its defence system was ready for new requirements. The SAF has constantly been marked by important transformational changes. Significant progress has been made in the area of increasing military

\footnotetext{
The agenda of the $8^{\text {th }}$ meeting of the Committee on Defence of the National Assembly of the Republic of Slovenia on 24 September 1997 included the following item: Assessment of the failed candidacy of Slovenia to join the first round of NATO enlargement, and development of a strategy for integration into NATO in the post-Madrid period. More on this at: http://www.dz-rs.si/wps/portal/Home/deloDZ/seje/evidenca? mandat=II\&type=magdt\& uid $=14 B A E A 86 E B 1 C B D F F C 125651 C 0042 E 5 B 7$.
} 
capabilities; the SAF has acquired new weapons and equipment, and increased the number of professional and contractual members.

The last conscripts finished their mandatory military service in 2003 and since then, we can speak of a professional army. Careers were becoming increasingly more important both for individuals and the organization; they had to be based on the acquired competencies needed to perform a specific duty and the associated advancement in the military hierarchy. With the transition from a conscript to a professional army, major changes were carried out, both in the mindset and the mode of operation. Due to the awareness of how difficult the transition from a conscript to a professional army is, the PROVOJ (professional armed forces) project was established in 2003, the purpose of which was to propose solutions and necessary activities to transition from a conscript to a professional army. The project also included and presented the possible risks.

Moreover, the intensity of individual and collective education and training increased. The SAF General Staff and its three subordinate operational commands underwent transformation with the establishment of the Force Command, thus clearly delineating the powers between the strategic and operational levels. Participation in the Partnership for Peace (PfP) programme was strengthened. The SAF was becoming more actively and intensely involved in international operations and missions as well as in international military exercises. In 2000, the SAF deployed its first members to Kosovo, and in 2004, to NATO's ISAF mission in Afghanistan.

The SAF increasingly contributed its capabilities to priority international ambitions, thus contributing to the securing of peace in the near and far international region. After joining the Alliance, the SAF was provided with new opportunities for cooperation with other armed forces of NATO member states. It participated in several joint training courses for operation under various conditions, in joint projects and experiments, in the lending of military equipment, in the exchange of data and other activities. Šteiner's opinion on the issue is the following: "In many areas, the beginnings of integration are closing the transition period, with the Republic of Slovenia and its armed forces credibly participating in defence and military structures and joint activities in both NATO and the EU. This particularly includes the activities of joint defence planning, participation in joint commands, integration into the Allied force structure, contribution to response forces, participation in international operations and missions, and the building of national capabilities which, through the doctrines and standards, are interoperable with others in the Alliance." (2011, p. 45).

Professionalization has also affected the command and control system which has to be rapidly responsive in order to allow the SAF to smoothly and properly perform its tasks in Slovenia and abroad. Worth mentioning is also the establishment of the noncommissioned chain of command and the NCO corps. The greatest changes occurred in the transition from a conscript to a professional army. NATO membership has had a significant influence on the processes of professionalization and integration in the SAF. 
The Mid-Term Defence Programme 2013-2018, adopted by the Government of the Republic of Slovenia, is an important development document for the SAF. The document defines the objectives and key guidelines for the operation and development of the Slovenian defence system in the mid-term period of 2013-2018. It takes into account Slovenia's financial capabilities in the relevant mid-term period, assuming to only allow for a minimum increase in defence expenditure after 2015.

The Mid-Term Defence Programme 2013-2018, p. 12/53, states: "For the purpose of operating on the Slovenian national territory, the highest unit provided by the SAF will be a special-purpose brigade battle group, while, for SAF operation outside Slovenia, its highest unit will be a special-purpose battalion battle group."

Since Slovenia joined the Alliance, the SAF has been more successful in some areas of development, and less in others. It is a fact that not enough financial resources have been invested in the modernization of firing ranges and training areas, and in the adaptation of barracks for the needs of a professional army. In the future, the SAF, the Ministry of Defence and other government bodies will be faced with new challenges in this area.

Due to the constant reductions in defence budget as a result of the financial situation in Slovenia, the SAF development challenges will have to be faced and accepted gradually by taking into account the financial and other capabilities, but mainly by applying tolerance and reason. It would also be wise to consider amending the Mid-Term Defence Programme 2013-2018, taking into consideration the real financial capabilities and allowing for mid- and long-term planning. Jelušič wrote: "The financial and economic crisis that we have witnessed will have a negative impact on the pace of development and modernization of the Slovenian defence system. Nevertheless, the development and modernization should not be stopped or frozen for several years, as this would signify a real setback (2009, p. 10)."

\section{SAF OPERATION ACTIVITIES IN INTERNATIONAL OPERATIONS AND MISSIONS}

Participation in international operations and missions is an important part of the common tasks of the Alliance ${ }^{3}$. International operations and missions are a place where the SAF can compare itself to its allies both in terms of competence as well as equipment and armament.

\footnotetext{
Article 37, paragraph 1 of the Defence Act states: "Execute obligations assumed by the state in international organizations and through treaties."

Article 22, paragraph 1, indent 2 of the Service in the Slovenian Armed Forces Act states: “...trough participation in operations, missions and other forms of operation appropriate for conflict prevention, peacekeeping, peace enforcement and collective defence."
} 
"The concept of peace operations, in its broadest sense, encompasses all forms of military and non-military activities taking place in the context of political and diplomatic efforts to establish and preserve peace." (Jelušič, 2005, p. 12).

The SAF's participation in international operations and missions is a direct contribution of the SAF to regional and global security, as peace in the narrower and wider region also guarantees peace in Slovenia, with the SAF's contribution being great and undeniable. From 1997 until today, approximately 4,700 SAF members have participated in international operations and missions, with the daily average of about 380 members. The first SAF unit participated in the peacekeeping operation Alba in Albania in 1997, then in Cyprus, in EU operation Althea in Bosnia and Herzegovina, in the UNTSO military observer mission in Syria, in the NATO KFOR operation in Kosovo since 2000, in the NATO ISAF operation in Afghanistan since 2004, in the NATO operation in Iraq, in the UN peacekeeping mission UNIFIL in Lebanon since 2006, in the EU's EUFOR operation in Chad in 2008 and 2009, in the naval operation EU NAVFOR Somalia in 2009, in the military observer mission UNSMIS in Syria, in the military operation EUTM Mali in 2012, and in the humanitarian operation Mare Nostrum - Lampedusa in 2013 and 2014. In these 17 years, the SAF has participated in international operations and missions of NATO, the EU and UN. In 2010, the Government of the Republic of Slovenia adopted the Strategy of the Participation of the Republic of Slovenia in International Operations and Missions, which is an important document for the operation of the SAF. The strategic interest of Slovenia is for the Western Balkans to become a peaceful, stable and developmentally progressive area of countries ${ }^{4}$. For this reason, for a number of years, the SAF has had the largest contingent of forces deployed in Kosovo, which is currently totalling 304 members. From the military perspective, participation in international operations and missions in countries such as Afghanistan, Iraq, Chad and Lebanon is very demanding, which is further emphasized by the distance of these countries.

International operations and missions bring a wealth of experience and are a major challenge to most SAF branches and services. The lessons learned through the system of learning from experience have a direct influence on the preparation of new SAF contingents and the SAF development. The year 2013 presented a special challenge to the SAF which prepared the military boat Triglav for participation in the humanitarian operation Mare Nostrum in Lampedusa. This was the first deployment of the military boat Triglav to an international operation. Given the total number of SAF members, counting 7,214 on 1 September 2014, the percentage of SAF participation in international operations and missions is high, which can also be seen from the table below.

\footnotetext{
4 Section 22 (Strategic Interests) of the Strategy of the Participation of the Republic of Slovenia in International Operations and Missions states: "Slovenia's strategic interests in participating in international operations and missions are determined by its geostrategic position, political, security, economic, development, humanitarian and other interests and principles, including obligations within the international organisations of which it is a member, at the global and regional levels. For all types of international operations and missions, except for rescue operations, strategic interests are defined primarily in South East Europe, as well as in Eastern Europe and the Caucasus, the Mediterranean, the Middle East, Asia, Africa and other regions in the world."
} 


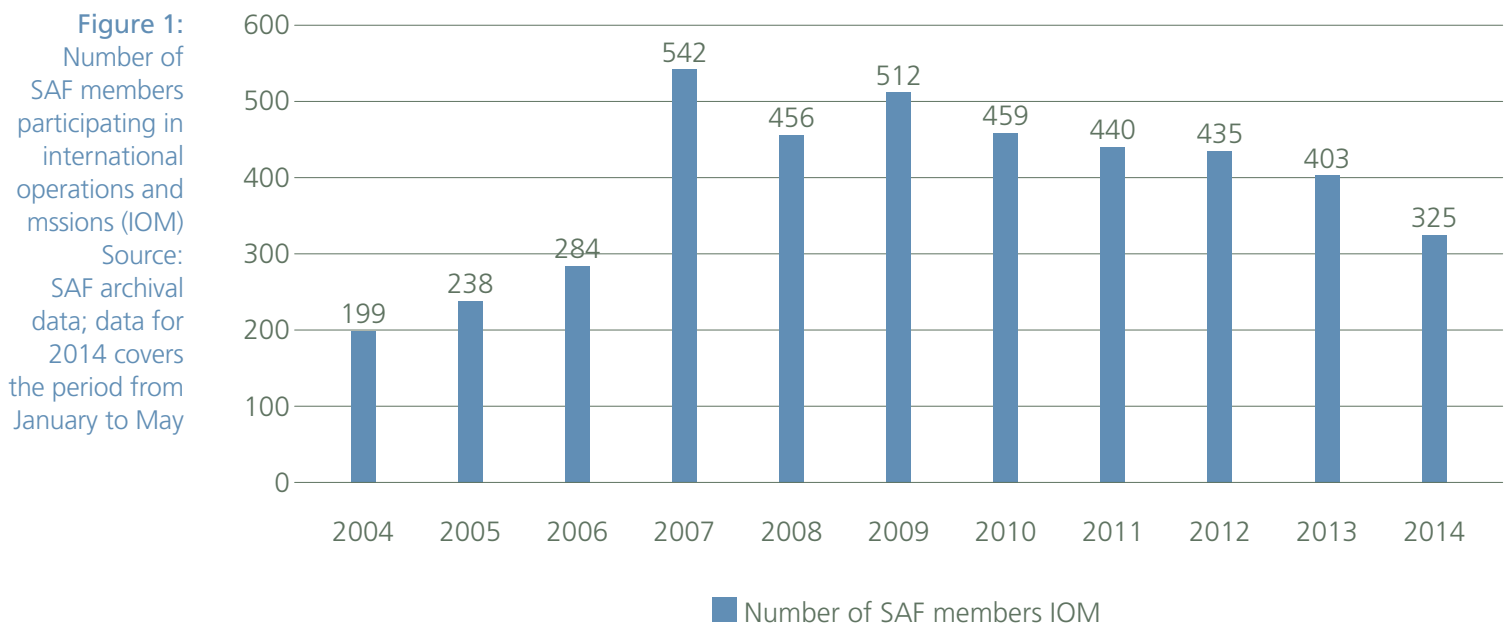

Each new SAF contingent in international operations and missions acquires new and invaluable experiences which are also relevant to NATO and the EU; each international operation and mission is therefore special and specific. The preparation of each contingent is a unique challenge, as each has its own peculiarities. During preparations, a contingent is given maximum attention in terms of equipment, to ensure the optimum safety of members, and training for the performance of the required tasks. The SAF's participation in international operations and missions has a positive impact on the SAF's development both in terms of equipment and training.

\section{IMPORTANCE OF INTERNATIONAL MILITARY EXERCISES FOR THE SAF}

Each international military exercise presents a special challenge to the SAF. The exercises are part of collective training to achieve the required standards, and to maintain and ensure the operational readiness. The combat orientation of peacetime training of units and commands allows for the implementation of the expected tasks in real combat situations. Through exercises, an individual is trained to understand his or her relationship within the unit and the fact that the performance of his or her task also supports the overall tasks of the team. ${ }^{5}$ Exercises are the highest form of collective training. By participating in NATO exercises, the SAF is meeting the national training objectives and the NATO's Connected Forces Initiative.

\footnotetext{
The Greek philosopher Aristotle said: "Excellence is an art won by training and habituation. We do not act rightly because we have virtue or excellence, but we rather have those because we have acted rightly. We are what we repeatedly do. Excellence, then, is not an act but a habit."

On 24 September 1776, in a letter to the President of Congress, George Washington wrote: "To bring men to an appropriate level of subordination is not the work of one day, month or year."
} 
Page 12 of the Bi-Sc Collective Training and Exercise Directive (CT\&ED 075-003) states, inter alia, that education and training provide a coherent and integrated system of training which directly contributes to the preservation of collectivity of national forces, the NATO Command Structure (NCS) and the NATO Force Structure (NFS), all of which are interoperable and include a full range of capabilities and structures which allow the Alliance to achieve the desired level of ambition in a rapidly evolving and uncertain security environment.

In all these years, the SAF has participated in a number of international exercises. Armed forces find a special challenge in the exercises where, at the end of the operational cycle, units' readiness is tested through the certification process. This is a process in which the use of various methods and examinations helps to determine whether a unit is ready for operation. National and NATO certifications are used.

In 2012, the SAF participated in 36 exercises, and in 2013 in 31 exercises. There are 45 international exercises planned for 2014. By participating in international military exercises, the SAF tests its degree of interoperability with the Allied forces. Great importance is placed on the exercises performed in the Joint Multinational Readiness Centre in Hohenfels, Germany, including different allied troops. This is an example of good practice before deploying a SAF contingent to an international operation or mission. In 2014, the international ISAF operation is gradually coming to an end, and NATO exercises are gaining importance. These exercises will include NATO commands and NATO Response Forces. International military exercises are important not only for the SAF, but also for Slovenia, making an active contribution to the development and effectiveness of NATO's military capabilities.

\section{STANDARDIZATION}

NATO standardization is very important for the achievement of interoperability among members of the Alliance. The implementation of NATO Standardization Agreements (STANAG) facilitates the attainment of the necessary level of interoperability among Alliance members to allow for the effective performance of common strategic, operational and tactical tasks within the command process, and for the effective use of technical assets, materials and administrative equipment. Interoperability is also an integral component of each NATO military capability, and an integral part of its capability development process. Interoperability is thus implemented through standardization. As I have already mentioned, "NATO STANAG is a unique regulation establishing the mandatory practices or technical requirements in the SAF, as there would be no international connectivity within the Alliance without it. It is therefore necessary to adopt NATO STANAGs into the Slovenian military standards." (Osterman 2010, p. 253)

This implementation process includes a precisely specified manner of producing, certifying and revoking the standardization documents. Operationally, this takes place in various NATO standardization committees and working groups which also 
include SAF representatives. The work in various NATO standardization working bodies is continuous and consistent. Undoubtedly, standardization also affects the shaping of SAF capabilities, particularly the purchase or new weapons and equipment, information and communication systems, the operation of logistics, the staff decision-making process etc.

The SAF started to adopt Slovenian military standards when Slovenia was a Partnership for Peace member, while this activity increased with the entry into NATO. Thus, from 2000 to September 2014, 728 NATO STANAGs have been nationally certified and 424 Slovenian military standards adopted. The above figures show that the validation and adoption of STANAGs were very intense.

\section{INVOLVEMENT OF SAF REPRESENTATIVES IN NATO COMMANDS AND WORKING BODIES}

In the context of NATO's Command and Force Structure, the SAF, by joining the Alliance, also assumed international military obligations. These enable the SAF to actively participate in NATO Commands, which is important for the command and control of NATO and EU military capabilities within various international operations and missions. "The EU military structure is younger and less developed than the NATO military structure. Slovenia participates in its development, planning forces for the EU military structure. Moreover, it participates in the rotation of European military battle groups; during the presidency it was also actively involved in activating the EU-led operation in Chad." (Humar et al., 2009, p. 61).

For the filling of international posts, SAF members are required to have all the professional competences arising from the requirements of each duty or post. From the personnel point of view, the filling of these posts is a demanding process, with certain duties also being deployable. Aside from the permanent duties in NATO Commands, the SAF is temporarily manning individual duty posts in commands with the so-called supplementary staff. The posting usually lasts 3 to 4 years. The experience gained by SAF members in international duty posts is very important for the operation of the SAF at various levels of command and control. When a member terminates his or her international duty, they are assigned to a post in which they can best use the experience acquired abroad. The SAF has gained considerable experience in all the years of operating in NATO and EU structures; it can be said that, within its powers, the SAF is a fully equal partner.

\section{TRANSFORMATION PROCESS IN NATO AND THE SLOVENIAN ARMED FORCES}

The globalization of the world and the emergence of new crisis areas compel the Alliance to follow these trends, despite the fact that, in most NATO countries, less and less resources are being devoted to the development of military capabilities. 
Thus, the international environment is constantly changing and becoming more and more unpredictable. ${ }^{6}$ The globalized world is also bringing changes to the armies in terms of their personnel structure, weapons and equipment, education and training methods etc. In recent years, many discussions and meetings in NATO structures have been devoted to this issue. In 2003, NATO established the Allied Command Transformation in Norfolk (USA) which is increasingly gaining importance. Through its projects and experiments, the Command is seeking appropriate solutions for the challenges which NATO will address in the future. It supports activities within the Smart Defence and the Connected Forces Initiative. Major emphasis is placed on the NATO Defence Planning Process and, in this context, on the Framework Nations Concept and the Connected Forces Initiative. With the establishment of the new NATO Command Structure, the Allied Command Transformation also assumed the area of military education and training. With the gradual withdrawal of the Allied forces from Afghanistan, NATO exercises will become increasingly important, as members will be preparing for future international operations and missions. We can conclude that the transformation process in NATO also influences the transformation of the SAF which is part of NATO's defence planning and participates in the Connected Forces Initiative and Smart Defence projects. Šteiner states: "The concept of transformation is characterized by new forms or a paradigm of change, with a tendency to become the new theory of changing the defence and military organization (2011, p. 46)."

Transformation as a concept is often present in the Alliance and national environments. It can be interpreted as a necessary process that allows the armed forces to adapt to changes in the environment, so that they can effectively perform their tasks. Therefore, transformation is a never-ending process, with the environment in which the armed forces operate constantly changing. The key factors in transformation activities are usually the amount of defence expenditure earmarked for the development of the armed forces, and, in relation to this, changes in the global security environment. In recent years, various NATO countries have decreased their defence spending, which is mainly due to the economic and financial crisis. ${ }^{7}$

The transformation of military capabilities as a new concept in the Alliance has been officially known since the NATO Summit in Prague in 2002 when the beginning of the period of the transformation of military capabilities was officially verified (NATO Handbook, 2006, p. 20); this gave rise to the establishment of the Allied Command Transformation (ACT). Clinton provides the following definition of

\footnotetext{
${ }^{6}$ Grizold (2005, pp. 22 -23) states: “... that, after the end of the Cold War, the international security environment has become increasingly unpredictable and uncertain. The fundamental characteristic of this environment is the complexity of security threats, which includes the following essential elements: integration, intertwining and interaction between military and non-military security threats (e.g. military and ethical conflicts, proliferation of weapons of mass destruction, organized crime, terrorism, natural and other disasters, famine, infectious diseases, environmental pollution etc.)."

The Strategic Foresight Analysis 2013 Report, page 29, states that "Governments faced with slow or nonexistent growth, rising unemployment and increasing debt burdens will continue to have many competing priorities. Defence spending has continued to decline across the Alliance due to reduced economic growth, and the increasing emphasis on social programmes. There is a risk that, even if economic cycles turn more positive, public opinion may prevent some nations from reinvesting in defence."
} 
transformation: "Transformation is a process that shapes the changing nature of competition and cooperation through new combinations of concepts, capabilities, people and organizations (Clinton, 2009, p. 2).

The SAF must follow the transformation policies taking place in the Alliance. The international financial situation has had a negative impact on defence budgets of most NATO countries (the same happened with the Slovenian defence budget), which in turn negatively impacts the development of military capabilities. The use of financial resources is subject to certain regulations which aim to maximize the impact of the resources used. ${ }^{8}$ The SAF transformation processes are thus directed towards the use of available resources being as efficient and rational as possible, and aims to maintain and achieve the performance objectives adopted during the Alliance negotiations or required for the implementation of the tasks of national importance, such as, for example, protection and rescue. The SAF thus had to transform in a way that it remained as efficient as possible, as the financial resources for its operations had reduced by 40 percent in just a few years. Moreover, government restrictions on employment also led to a smaller number of SAF employees.

Figure 2:

Military defence programme

Source: SAF archival data $^{9}$

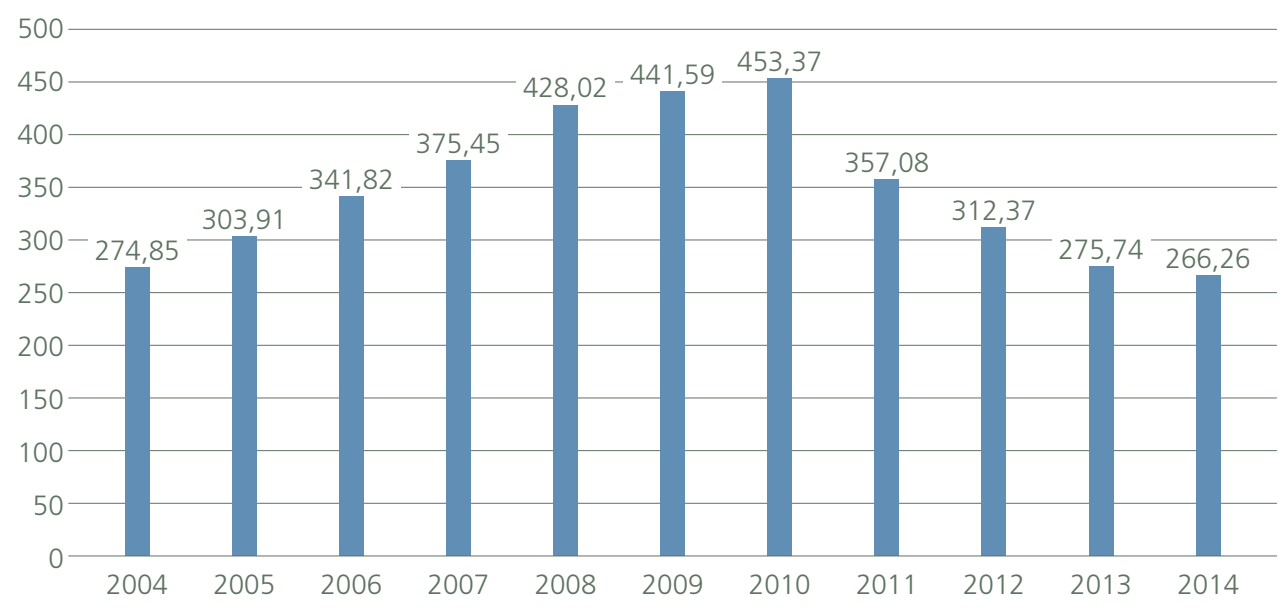

Financial resources

8 Kopač (2011, p. 174) believes: "It is a fact that, in the last ten years, the Republic of Slovenia has seen a considerable improvement in the institutional rules that promote a more efficient provision of military capabilities. In this regard, in addition to increasing the awareness that we cannot afford irrational use of public resources, it is important to integrate into the Euro-Atlantic structures. Defence planning is thus developing in accordance with the defence planning process of NATO and the European Union. Military investments are subject to a number of EU directives governing public procurement in general and specifically procurement in the areas of defence and security."

9 The graph presents the SAF budget which, within the state budget, is managed in the context of the Defence and Security policy (07), Military Defence programme (0702). 
Therefore, certain issues, with the aim of providing and developing military capabilities, will be resolved through participation in Smart Defence projects, the Connected Forces Initiative and the Framework Nations Concept. It can be established that the transformation processes in NATO also affect the transformation processes in the SAF.

Figure 3:

Percentage of

GDP in Slovenia

earmarked

for defence

spending

Source:

SAF archival

data

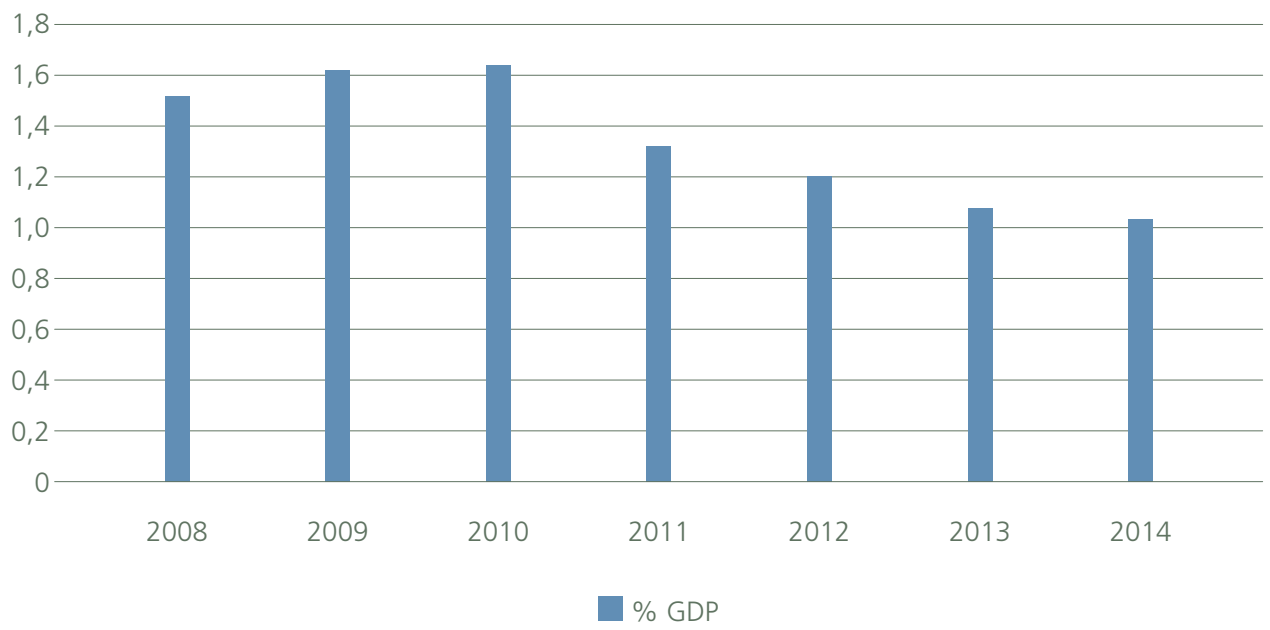

It should be noted that defence expenditure in 2009 and 2010 accounted for approximately 1.62 percent of GDP of Slovenia, and 1.04 percent in 2014, which signifies a marked decline in defence spending in a very short period of time ${ }^{10}$. The NATO arrangement is that Member States should commit 2 percent of GDP to defence spending.

\subsection{Smart Defence, the Connected Forces Initiative and the Framework Nations Concept as Assistance in the Development of SAF Capabilities}

Smart Defence includes multinational cooperation in the development, procurement, maintenance and use of capabilities, the implementation of priority tasks in line with the NATO strategic priority tasks and the identified deficits from operations, as well as the specialization of forces and the division of roles among the Allies. Slovenia participates in several projects. ${ }^{11}$ These projects are included in the first-order set of Smart Defence projects, since proposals have grown and developed into projects with an identified framework nation, participating countries having confirmed their participation, and the agreed scope and purpose of the programme having been

${ }^{10}$ In addition to the SAF budget, defence expenditure includes the defence system management and crisis management programme (administrative part of the Ministry of Defence), military pensions and the budget of the Government Office for the Protection of Classified Information.

${ }^{\prime \prime}$ Smart Defence - presented at the Munich Security Conference in February 2011 by the NATO Secretary General Anders Fogh Rasmussen. 
coordinated. One of the major SAF projects is also development of the CBRN defence capabilities. Other projects that the SAF participates in are primarily related to education, training and equipment procurement. In the selection of projects, longand mid-term development documents must be taken into consideration to ensure that the content matches the objectives set out in these documents. In recent years, Cyber Defence projects are increasingly coming to the forefront in the Alliance, offering a variety of opportunities for the training of SAF members. The selection should be focused on the projects that bring the maximum effect in terms of security provision, taking into account the SAF's financial capabilities.

The Connected Forces Initiative signifies an improvement in interoperability between the Allied and partner forces, and connection between the NATO and national commands through joint education, training, exercises and technological solutions. ${ }^{12}$ We believe that exercises are a specific area for verifying and assessing the ability to operate collectively in the Alliance and NATO-led coalitions based on the domains of doctrines, procedures, organizations, training and equipment. In its role, NATO must offer countries the opportunity to improve their interoperability through a range of available, flexible and affordable joint events. These will enable the Alliance and countries to rapidly adapt to any changing circumstances and demands of the emerging challenges. The aim is to maintain and improve NATO's preparedness, interoperability and combat efficiency between the Allied and partner forces and capabilities, through the expanded programme of training and military exercises. In the context of the Connected Forces Initiative, NATO Response Forces will have a central role of a facilitator and demonstrator of operational readiness and will be the benchmark for NATO's transformation. The Initiative enables the SAF to connect with the operational experiences within NATO. In the anticipation of reducing the operational activities of NATO after the completion of the ISAF operation in 2014, this Initiative will gain further importance. This year, the SAF has a section of the Special Operations Unit participating in NATO Response Forces. In the future, the implementation of several large-scale and quality exercises is planned in the context of a wide range of scenarios and consistent with the level of ambition; the SAF thus attaches great importance to the integration of national and NATO exercises. In 2015, the SAF will participate in the international military exercise Trident Juncture 2015.

The Framework Nations Concept aims to provide the European allies, during the period of reducing defence resources and the USA's strategic redirection, the required capabilities in an organized manner and assume a relative burden and responsibility for the common security and defence. ${ }^{13}$ The Concept is focused on the formation of groups of countries under the auspices of framework nations, which would provide comprehensive sets of capabilities. Framework nations with a broader range of capabilities would connect smaller countries with specialized

\footnotetext{
12 Connected Forces Initiative - arises from the Chicago Defence Package adopted in May 2012.

${ }^{13}$ Framework Nations Concept - first discussed at the ministerial meeting in June 2013, presented in detail to Member States in September 2013.
} 
contributions, bringing them relief and enabling them to focus their resources on the development of specialized capabilities - each ally, however, would have to maintain a credible combat capability. The Concept is an upgrade of the current multinational approaches, as it provides for a long-term partnership in the field of providing the full spectrum of capabilities, while the Smart Defence project and the project of pooling and sharing are focused on the development of individual capabilities. The Framework Nations Concept is a German initiative drawing on the positive experiences gained through the implementation of multinational projects and the establishment of a framework nation in the organization of operational forces and the conduct of international operations and missions. The SAF has a positive experience of cooperation in multinational forces under the auspices of a framework nation, both in the integration of forces within the NATO Response Force and the Multinational Land Force, as well as in international operations and missions. Both the Connected Forces Initiative and the Framework Nations Concept are of great importance to the SAF, especially now that fewer budgetary resources are earmarked for the development and operation of the Slovenian Armed Forces. The importance of these concepts was addressed by the NATO Secretary General Anders Fogh Rasmussen at the round table in Ljubljana on 24 January 2014.

\subsection{SAF Transformation Processes}

Since the entry into NATO, the SAF has been constantly changing. In some periods, transformation processes were more intense, in others less. But almost no year passed without any organizational changes in the formation structure of units and commands. These transformations were also considered in the findings of the Strategic Defence Review which was prepared in 2009. Major transformational changes were determined by the adoption of the Mid-Term Defence Programme 2013-2018. By transforming the tactical level of command in the first and second phase, which started in 2012 and was completed last year, the target organizational structure was established, allowing for the efficient performance of the SAF's tasks. This year, the SAF has entered the third phase of transformation. In this phase, the General Staff of the Slovenian Armed Forces has been transformed; a new concept of logistics operations is being established, and the identification of possible process and functional integration with the administrative part of the Ministry of Defence is being implemented. This phase of transformation will end with the establishment of two balanced infantry brigades, as the core of SAF development and operation, and the centralization of logistics support. In the field of civil-military cooperation and the system of protection and rescue, both infantry brigades will be even more spatially positioned.

The SAF entered the year 2014 with the military budget (the military defence programme) of EUR 266 million; in 2013, the military budget amounted to EUR 300 million. Thus, there is a growing gap between the requirements set out in the Mid-Term Defence Programme 2013-2018 and the amount of budgetary resources provided for the realization of this and other documents. This is the complete opposite of the need for the procurement of equipment and weapons, and prevents 
the realization of certain requirements. This negative financial trend calls for a rapid transformation and the provision of a sustained system with very limited financial resources; moreover, it calls for the realization of the planned tasks through the timely and effective adoption of measures. The SAF efficiency is also achieved through the rapid response of the command and control system. Irrespective of the reduction of budgetary resources, the SAF will have to maintain and upgrade the already achieved standards in individual and collective competence.

The SAF's transformation is an ongoing process responding to external changes. Looking at the time from Slovenia's entry into NATO until today, the greatest transformational changes were caused by transitioning from a conscript to a professional army, with the development progress of the SAF being very evident. The most important transformation challenge today is how to provide adequate military capabilities to implement tasks in Slovenia and abroad with the available budget funding. The SAF's fundamental future challenge and capability goal for NATO is the establishment of a medium battalion battle group. An important contribution of Slovenia to the Alliance will be the establishment of the Multinational Centre of Excellence for Mountain Warfare in 2015, since the majority of NATO countries have already established various centres which are operating successfully today. Slovenia is the co-founder of some of them ${ }^{14}$. We should also not overlook the fact that the SAF plays an important role in its narrow region, providing mentorship to some other countries in the Balkans which are in the process of integration into the Alliance. Moreover, in the past, the SAF initiated the establishment of Multinational Land Force. International activities also affect the SAF's transformation processes in the forefront of which must be the provision of military protection and rescue capabilities, which is one of the SAF's tasks ${ }^{15}$. A large part of the equipment at the SAF's disposal thus has dual purpose.

Conclusion NATO has adopted the New Strategic Concept ${ }^{16}$ and is using conferences and consultations to discuss various transformation challenges that aim to transform NATO structures. The NATO Command Structure and NATO Force Structure are thus transformed. Due to the decline in defence spending in some NATO countries, Smart Defence, the Connected Forces Initiative and the Framework Nations Concept are gaining importance as cornerstones of joint military capabilities. This trend should also be followed by the SAF, mainly because the defence spending has reduced considerably in recent years and amounts to approximately 1.04 percent of Slovenia's GDP.

\footnotetext{
${ }^{14}$ Fifteen NATO countries have already established centres of excellence, namely Germany, Norway, the Netherlands, Belgium, France, Spain, USA, Estonia, Lithuania, Czech Republic, Slovakia, Hungary, Romania, Turkey and Italy. Currently, centres of excellence are being established in Poland, Latvia, Bulgaria, Italy and Slovenia.

${ }_{15}$ Article 37, paragraph 1 of the Defence Act states: "Participate in protection and rescue activities in the event of natural and other disasters in line with its organization and equipment."

${ }_{16}$ Strategic Concept for the Defence and Security of the Members of the North Atlantic Treaty Organization was adopted at the NATO Summit in Lisbon between 19 and 20 November 2010.
} 
It is thus evident that the SAF has made considerable progress since joining NATO. Due to the continuous shrinking of financial resources for defence, the ratio between the costs of personnel, operational performance and equipment (modernization) is becoming less favourable and is increasingly moving away from the recommended ratio of the Alliance. The SAF must therefore use transformation processes to adapt quickly and maximize the use of resources available for the provision of military capabilities for national needs and the needs of the Alliance. It must be small, efficient, sustainable and as deployable as possible to be able to operate in various scenarios within the Alliance. In the ten years, the SAF has gained a lot of experience in operating within the Alliance. Its proposals and initiatives make it an active creator in NATO. The SAF should also build military capabilities and participate in international military exercises. It must transform the Multinational Centre of Excellence for Mountain Warfare into the NATO Centre of Excellence for Mountain Warfare, continue the work of the School of Foreign Languages, organize other schools for the needs of the region and be a mentor to countries in South East Europe. It must continue to be internationally recognized by its contribution to international operations and missions etc. Slovenia's membership in NATO has enabled the SAF to contribute to the Alliance and thus gain added value itself. The SAF will have to continue the process of professionalization, and occupy higher military positions and posts in the NATO Command Structure and NATO Force Structure, which provide most direct operational experience.

Based on the analyses of projects and in terms of time correlation with the national programmes and available financial, material and human resources, the SAF must participate in Smart Defence projects, the Connected Forces Initiative and the Framework Nations Concept. Due to the lack of financial resources it should take advantage of all the personnel and material resources, allowing for and supporting innovative and creative thinking at all levels of command and control.

Entry into the Alliance has brought changes to the personnel structure which is gaining in quality; there has been an increase in military capabilities in the area of command and control as well as in sustainability, combat power and deployability. Part of military capabilities has dual purpose, providing support to the defence system and the system of protection against natural and other disasters. Due to the rapid reduction of the defence budget or funds earmarked for defence expenditure, further development of the SAF will require deliberation of its future scope and structure, based on stable budgetary financing as the basis for mid- and long-term planning of the development of military capabilities. Due to the major differences between the requirements set out in development guidance documents and the available amount of budgetary resources for the realization, it will, in the future, be necessary to ensure mutual consistency. Today, the lack of financial resources is mainly reflected in certain equipment and weapons necessary for the realization of capability goals, maintenance of military infrastructure etc. The fundamental challenge and objective for the future of the SAF must be the development of planned capabilities both for the needs of the Alliance and the national needs. 


\section{Bibliography}

1. Bi-Sc Collective Training and Exercise Directive (CT\&ED) 075-003, accessed on 22 May 2014 at http://www.act.nato.int/images/stories/structure/jft/bi-sc-75-3_final.pdf.

2. Clinton, H. (2009). In V Grant Hammond, The International Transformation Chairs Network. Editors: Derrick Neal, Henrik Friman, Ralph Doughty, Linton Wells II. Crosscutting Issues in International Transformation, Interactions and Innovations among People, Organizations, Processes, and Technology. The Center for Technology and National Security Policy. National Defence University, DC. 2009.

3. Grizold, A. (2005). Slovenija v spremenjenem varnostnem okolju. Ljubljana, Faculty of Social Sciences.

4. Humar, D., Mikuž, I., Zanoškar, S., Groff, D. and Holc, L., 2009. Vključevanje Slovenske vojske v Nato in vojaško strukturo Evropske unije (Integration of the Slovenian Armed Forces into NATO and EU military structures). In: Sodobni vojaški izzivi (Contemporary Military Challenges) 11/No. 3 (November 2009): pp: $59-81$.

5. Jelušič, L., 2013. Po petih letih članstva v zvezi Nato - Presenetljivo dobro za Slovenijo (Surprising Achievements of Slovenia After Five Years of NATO Membership). In: Sodobni vojaški izzivi (Contemporary Military Challenges) 11/No. 3 (November 2009): pp: 7 - 13.

6. Jelušič, L. (2005). Mirovne operacije in vloga Slovenije. Ljubljana: Faculty of Social Sciences.

7. Kopač, E., 2011. Učinkovito zagotavljanje vojaških zmogljivosti (Effective Provision of Military Capabilities). In: Sodobni vojaški izzivi (Contemporary Military Challenges) 13/ No. 2 (June 2011): pp: 163 - 176.

8. NATO Public Diplomacy Division (2006). Nato Handbook. Brussels. Public Diplomacy Division.

9. Osterman, A. (2010). Doctoral thesis - Normativna ustreznost ureditve delovanja logistike Slovenske vojske v sistemu logistike. Celje: faculty of Logistics.

10. RESOLUCIJA o strategiji nacionalne varnosti Republike Slovenije (ReSVN) (Resolution on the National Security Strategy of the Republic of Slovenia). Uradni list RS (Official Gazette of the Republic of Slovenia) No. 56/2001.

11. RESOLUCIJA o strategiji nacionalne varnosti Republike Slovenije (ReSVN-1) (Resolution on the National Security Strategy of the Republic of Slovenia). Uradni list RS (Official Gazette of the Republic of Slovenia) No. 27/2010.

12. Srednjeročni obrambni program 2013 - 2018 (Mid-Term Defence Programme 2013 - 2018): http://www.mo.gov.si/fileadmin/mo.gov.si/pageuploads/pdf/predpisi/ obramba/SOPR2013_2018.pdfUradni list RS (Official Gazette of the Republic of Slovenia) No. 103/2004 (22 May 2014).

13. Strateški pregled obrambe (2009). Ljubljana: Ministry of Defence of the Republic of Slovenia.

14. Strategija sodelovanja Republike Slovenije v mednarodnih operacijah in misijah. Uradni list RS (Official gazette of the Republic of Slovenia) No. 19/2010.

15. Strategic Concept for the Defence and Security of the Members of the North Atlantic Treaty Organization: http://www.nato.int/nato_static/assets/pdf/pdf publications/20120214_strategic-concept-2010-eng.pdf (22 May 2014).

16. Strategic Foresight Analysis 2013 Report, accessed at: http://www.act.nato.int/sfa-report (22 May 2014).

17. Šteiner, A., 2011. Transformacija - jo hočemo, jo zmoremo? (Transformation - Do We Want It, Can We Manage It?). In: Sodobni vojaški izzivi (Contemporary Military Challenges) 13/No. 2 (June 2011): pp. $43-60$.

18. Zakon o obrambi (Defence Act). Uradni list RS (Official Gazette of the Republic of Slovenia) No. 103/2004-UPB1 (official consolidated text), 138/2004 Skl.US: U-I-329/047, 53/2005 Skl.US: U-I-329/04-15, $117 / 2007$ Odl.US: UI-287/05-20, 46/2010 Odl.US: U-I-92/07-23.

19. Zakon o službi v Slovenski vojski (Service in the Slovenian Armed Forces Act). Uradni list RS (Official gazette of the Republic of Slovenia) Nos. 68/2007 and 58/2008- ZSPJS-I. 